\title{
Gender Differences in Extreme Mathematical Achievement: An International Perspective on Biological and Social Factors $^{1}$
}

Andrew M. Penner

University of California, Irvine

Genetic and other biological explanations have reemerged in recent scholarship on the underrepresentation of women in mathematics and the sciences. This study engages this debate by using international data-including math achievement scores from the Third International Mathematics and Sciences Study and country-level data from the World Bank, the United Nations, the International Labour Organization, the World Values Survey, and the International Social Survey Programme- to demonstrate the importance of social factors and to estimate an upper bound for the impact of genetic factors. The author argues that international variation provides a valuable opportunity to present simple and powerful arguments for the continued importance of social factors. In addition, where previous research has, by and large, focused on differences in population means, this work examines gender differences throughout the distribution. The article shows that there is considerable variation in gender differences internationally, a finding not easily explained by strictly biological theories. Modeling the cross-national variation in gender differences with country-level predictors reveals that differences among high achievers are related to gender inequality in the labor market and differences in the overall status of men and women.

\section{INTRODUCTION}

The underrepresentation of women in mathematics and the sciences has been the subject of much academic debate. The broad interest in this

\footnotetext{
${ }^{1}$ I am grateful to Neil Fligstein, Mike Hout, Trond Petersen, Jim Powell, Paul Ruud, and Robb Willer for useful comments and discussions. Direct correspondence to Andrew M. Penner, Department of Sociology, University of California, Irvine, California 92697-5100. E-mail: andrew.penner@uci.edu

(C) 2008 by The University of Chicago. All rights reserved. 0002-9602/2008/114suppl-0005 $\$ 10.00$
}

S138 AJS Volume 114 Suppl. (2008): S138-S170 
Gender and Math Achievement

topic arises for two reasons. First, the underrepresentation of women in fields related to mathematics and science is one of the most persistent vestiges of occupational segregation and gender inequality. While the women's movement has made great strides in many arenas, achieving equal representation of men and women in mathematics- and sciencerelated fields has proved remarkably difficult. There is thus considerable interest in understanding this issue in order to gain insight into the processes at play in occupational gender segregation, particularly in situations where it seems intractable. Second, the underrepresentation of women in mathematics and the sciences is tied to concerns about the human capital of the U.S. workforce. Given the growing importance of science-related jobs in the economy, the specter of severe human capital shortages in this area ensures that gender differences in high-level mathematical achievement receive a certain amount of attention. This consideration is particularly prevalent in policy-oriented discussions (see, e.g., U.S. Congress 2000).

The discussion around the underrepresentation of women in mathematics and the sciences includes issues of aptitudes, inclinations, and structural barriers. Of these, the most contentious and volatile issue is whether men and women have a similar aptitude for mathematics and science, an issue that taps into a long-standing debate over differences in intellectual abilities between men and women. Historically, male superiority has been assumed. Darwin, for example, claimed that "man is more courageous, pugnacious and energetic than woman, and has a more inventive genius" (1897, p. 557). More recently, research has focused on the role that social factors have in creating gender differences in test scores (e.g., Spencer et al. 1999). The dominant paradigm is currently such that scholars arguing that biological gender differences have ramifications for intellectual abilities often note that they are broaching a taboo subject (e.g., Pinker 2002; Baron-Cohen 2003).

In spite of the current zeitgeist, recent scholarship has witnessed the resurgence of a variety of biological explanations for gender differences in mathematical performance. Geary (1998), for example, posits an evolutionary explanation, while Kimura (1999) proposes a hormonal theory. Baron-Cohen (2003) argues that there is a cerebral basis, suggesting that males and females have different brain types, so that women are better at empathizing while men are better at systematizing. While some researchers of biological gender differences in mathematics achievement argue that it is important to keep cultural factors in mind, others seem to regard biology as an immutable destiny (Blum 1997).

Despite the growing literature on the potential importance of biological considerations in mathematics, it is difficult to know how to think about questions involving innate biological factors, as it is impossible to examine 


\section{American Journal of Sociology}

people apart from either their physical bodies or their social contexts. Given the inextricable link between the biological and the social, one way to proceed is through examining these differences internationally. An international perspective is useful here because there is no reason to believe that the genetic factors involved in determining gender will vary across countries, implying that to the degree that gender differences in mathematics result from genetic factors, there should be no international variation in these differences. ${ }^{2}$ International data can thus provide an intuitive and straightforward way to demonstrate the importance of social factors. There is relatively little nuance involved: if gender differences vary across countries (and they do), then social factors are important. ${ }^{3}$ International variation also enables us to obtain a conservative estimate for the upper bound of the proportion of the gender gap accounted for by strictly genetic factors, because while the smallest country-level gender difference could be the result of genetic factors, the difference between this and any larger differences must be caused by social factors. In addition, international variation allows us to examine what kinds of countries have larger and smaller gender differences in mathematics achievement, providing a sense of how macrolevel societal factors influence gender differences in mathematics.

To make use of this international variation, this article takes two analytical approaches. First, I examine descriptive statistics on gender differences across countries. This analytical approach involves not only examining gender differences in basic descriptive statistics like means and variances, but also examining gender differences throughout the distribution. The second analytical approach involves modeling the crossnational variation in gender differences throughout the distribution with country-level predictors. Where the first approach establishes the importance of societal factors, the second reveals what specific societal factors are related to gender differences in mathematics achievement. In both of these approaches, I respond to previous work calling for an understanding of differences in populations that encompasses more than just their central tendencies (see, e.g., Favreau and Everett 1996; Handcock and Morris 1999). This is important not only because genetic theories about gender

\footnotetext{
${ }^{2}$ While some make a distinction between sex (biological) and gender (social), I do not believe that this is particularly useful in this context, given the inextricable nature of the link between sex and gender here. Thus, I use the term gender throughout the article.

${ }^{3}$ It is important to note that this is not the same as saying that biological factors are unimportant. As an example, it could be that diet interacts with hormones so that the gender differences we observe are in some sense biological, but social factors are still central. International variation thus precludes a deterministic biological account but is eminently compatible with biosocial interactions.
} 
Gender and Math Achievement

differences in mathematics make arguments about differences throughout the distribution, but also because the underrepresentation of women in mathematics and science related fields is more closely related to differences at the top of the distribution than differences in the mean.

Ultimately, the work of identifying the role of biology and genetics in creating gender differences in mathematics achievement falls to biologists and geneticists. But whatever biologists find, there is also no question that social factors have had and will continue to have major effects. Biological bodies provide us with both opportunities and constraints, and in different societies it is possible for different people to mobilize these opportunities and constraints to different degrees. If, as Freeman Dyson (2007) argues, the 21st century is the century of biology, then understanding how it is that social and biological factors interact provides one of the great challenges and opportunities for the social sciences. In the dialogue that social scientists are increasingly entering into with biologists, it is thus important to have a firm grasp on how social factors matter and how they might interact with biological factors.

Although it is difficult to know exactly how these biosocial interactions operate, one possibility follows from Guo and Stearn's (2002) work showing that there is greater genetic expression among high SES families, so that children in these families are better able to realize their genetic potential. It is easy to imagine a similar mechanism at play for gender differences in mathematics, where social factors enable boys to better realize their genetic potential than girls. Thus, while I discuss genetic and environmental factors separately for heuristic purposes, it is important to remember that they are better thought of as interdependent.

I proceed by outlining how biological and societal factors could create gender differences in mathematics. I then discuss the data and methods used in this article and present the results of my analyses. I conclude by discussing the implications of my findings for genetic hypotheses surrounding gender differences in mathematics and suggesting avenues for future research.

\section{THE BIOLOGICAL PRODUCTION OF GENDER DIFFERENCES IN MATHEMATICS}

Although this study does not examine biological factors directly, I briefly review the major biological theories relevant to gender differences in mathematics to provide a sense of this literature. Biological explanations for gender differences in mathematics achievement can be roughly grouped into three categories: genetic, hormonal, and cerebral, and they tend to focus on measurements of general intelligence and its specific 
American Journal of Sociology

components, especially spatial abilities (Benbow 1988; Casey et al. 1997; Halpern 2000).

\section{Genetic Considerations}

Given the role of genes in determining gender, it is not surprising that theories attributing gender differences in mathematics achievement to genetic differences exist. Studies typically find that around 50\% of general intelligence is accounted for by heredity (McClearn et al. 1997; Petrill 1997; Plomin et al. 1997), although as Plomin et al. (1997) note, this is an average and likely varies in extreme environments. ${ }^{4}$ While there is considerable evidence that both general intelligence and spatial abilities are inherited genetically, and even some work investigating the genes involved (e.g., Plomin and Craig 2001), in order for genetic influences to account for gender differences in mathematics achievement, gender differences in inheritances are necessary. Although early studies purported to evince the sex-linked recessive gene theory (Bock and Kolakowski 1973), which claims that a recessive gene for high spatial ability is carried on the $\mathrm{X}$ chromosome, later studies could not replicate this finding (see, e.g., DeFries et al. 1976). Boles (1980), in a review of the literature, concludes that there is no convincing evidence for the sex-linked recessive gene theory, though Thomas and Kail (1991) argue that Boles's dismissal of this theory is premature.

More recent work by Geary (1998) suggests that sexual selection could drive the underrepresentation of women at the top of the distribution by creating greater variability among males than females. Specifically, Geary (1998) posits that sexual selection might have resulted in males' being more responsive to environmental conditions than females, so that adverse environmental conditions would result in more boys at the bottom of the distribution, while beneficent environmental conditions would result in more boys at the top. According to this logic, a combination of adverse and beneficent conditions would result in greater male variability.

In general, while research has moved away from studies looking for a spatial abilities gene (e.g., the sex-linked recessive gene theory), genes still play a prominent role in this arena due to their influence on other biological considerations (Blum 1997).

\footnotetext{
${ }^{4}$ This raises an interesting question, as it suggests that most of the estimates that we receive about the relative importance of genetic vs. environmental influences are in contexts with relatively homogenous environmental considerations and thus underestimate the amount of variation attributable to the environment. It is possible, e.g., that estimates of the genetic and environmental portions of the variance in cognitive abilities might differ if estimated in a context where international environmental differences were able to be taken into account.
} 
Gender and Math Achievement

\section{Hormonal Considerations}

The relevance of hormones to gender differences in spatial ability is visible in the literature linking natural variation in hormones to performance on tests of spatial abilities. Hampson (1990), for example, shows that menstrual cycle variation in estradiol influences spatial abilities, and studies examining testosterone fluctuations across seasons (Kimura and Hampson 1994) and the time of day (Moffat and Hampson 1996) find evidence that testosterone levels also affect spatial abilities. In reviewing this literature, Kimura (1999) suggests that there is an optimal level of testosterone for spatial performance and that this level falls at the low end of the male range. Thus, we would expect the highest levels of mathematical achievement from females with high levels of testosterone and males with low levels of testosterone. This curvilinear relationship between testosterone and spatial abilities is also supported by research on people with congenital adrenal hyperplasia $(\mathrm{CAH})$, a condition that results in the overproduction of an androgen similar to testosterone. While women with $\mathrm{CAH}$ are found to have higher spatial abilities than other women, men with CAH have, if anything, lower spatial abilities than other men (Resnick and Bouchard 1986; Hampson and Altmann 1998).

\section{Cerebral Considerations}

Cerebral theories of gender differences in mathematics typically focus on brain lateralization. Generally these theories are based on the finding that males have more asymmetrically organized brains than females (Halpern 2000). This means that spatial abilities tend to be processed in both hemispheres in females and in one hemisphere in males. Evidence of this is found in studies showing that, in men, damage to the left hemisphere results in decreased verbal abilities, and damage to the right hemisphere in decreased spatial abilities, while in women, damage to the left hemisphere results in equal decreases in verbal and spatial abilities, and damage to the right does not seem to decrease either (Gazzaniga et al. 1998). Electroencephalogram (EEG) research on people with normally functioning brains finds that males perform better on a spatial task and tend to access their right hemisphere more than their left, while females exhibit greater degrees of bilateral activity (Gill and O'Boyle 1997). However, it is not clear that one way of processing is more efficient than the other. Levy (1974) hypothesizes that hemispheric specialization is the optimal neural organization for performing spatial tasks, but Halpern (2000) notes that data from left-handers does not support this. Bryden (1986) and Geschwind and Galaburda (1987), however, find that greater hemisphere specification could contribute to gender differences in spatial and math- 
American Journal of Sociology

ematical differences, as they find that right-handers exhibiting greater right-hemisphere specialization for nonlinguistic tasks tend to have higher spatial abilities.

\section{THE SOCIAL PRODUCTION OF GENDER DIFFERENCES IN MATHEMATICS}

While most social theories examine the impact of microlevel social considerations like parent, teacher, and peer effects (e.g., Ma 2001), this study explores broader issues of national context. Although analyses of gender differences in mathematics achievement typically take broader cultural settings as given, by exploiting variation in national contexts I am able to explore systematically how differences in this macrolevel context are related to the mathematics gender gap in that country. There are at least two ways in which national-level factors could play a significant role in creating gender differences in mathematics: first, through creating incentive structures, and second, through establishing gender differences in status.

\section{Incentive Structures}

Country-level social inequalities can be thought of as providing different incentive structures within which students decide whether to pursue mathematics education. Riegle-Crumb (2005), for example, uses international data to argue that girls in school look to the kinds of opportunities that are available to women in their society in determining whether to pursue mathematics and science education. This suggests that when boys and girls are deciding what courses to take, how hard to work on their homework, and otherwise where to invest their human capital, they do so with a knowledge of the kinds of opportunities that are realistically available to them. From this perspective, we can understand girls' underachievement in mathematics as a rational response to the perceived lack of opportunities for women in fields where mathematics achievement is valued. Frank et al. (2008) argue that this rational choice process includes not only future costs and benefits, but also more immediate social considerations such as popularity. Here too it is easy to imagine that national contexts would affect gender differences in mathematics achievement, in this scenario by dictating how popular mathematics is. Thus, regardless of the precise time horizon under which students are performing their cost-benefit analyses, it is reasonable to expect that differences in national contexts will alter students' decisions and result in different gender gaps in mathematics achievement. 
Gender and Math Achievement

Status

Findings from the social psychological literature on status suggest that national contexts are important not only in determining the incentive structure within which decisions are made, but that national contexts could also influence achievement through creating general gender differences in status and making gender more or less salient to mathematics achievement. The sociological literature on status characteristics theory suggests that beliefs and stereotypes about status characteristics have a broad range of effects. Especially relevant to gender differences in mathematics are findings of status effects on cognitive performance (Lovaglia et al. 1998) and self-perceptions of performance (Correll 2004).

The psychological analog of status characteristics theory focuses on stereotype threat effects, with similar findings. Stereotype threat research finds that when gender is made salient prior to administering a mathematics test, women score lower and men score higher than when gender is not made salient (Spencer et al. 1999; Walton and Cohen 2003). Stereotype threat effects in mathematics can be evoked with stimuli as diverse and subtle as a mixed-gender setting (Inzlicht and Ben-Zeev 2000), genderstereotyped television commercials (Davies et al. 2002), and telling subjects that gender differences are due to genetic (as opposed to social) factors (Dar-Nimrod and Heine 2006). These findings suggest that stereotype threat effects could have quite a substantial scope and that country-level factors such as the representation of women in the media and beliefs about the biological origin of gender differences in mathematics could be important. Taken together, research on stereotypes and status characteristics suggests that larger sociocultural factors might influence gender differences in mathematics achievement through their effect on gender schemas at the national level.

\section{DATA}

Data for this study come from several sources. Mathematics achievement scores are obtained from the Third International Mathematics and Sciences Study (TIMSS). Gender differences in these scores are modeled using country-level data from the World Bank, the United Nations, the International Labour Organization, the World Values Survey, and the International Social Survey Programme.

Mathematics Data

Mathematics data for this article are from TIMSS, which was conducted by the International Association for the Evaluation of Educational 
American Journal of Sociology

Achievement (IEA) in 1995. TIMSS includes information from over 40 countries and measures mathematics and science achievement in elementary, middle, and high school. This study analyzes mathematics literacy scores from the 22 countries with information on students in their final year of secondary school. ${ }^{5}$ A two-stage stratified sample was used within each of the countries, with schools sampled with probability-proportionalto-size at the national level and a fixed number of students from different categories (e.g., students who have taken advanced mathematics courses as opposed to those who have taken only basic mathematics) sampled from each school. Weights are thus used to obtain nationally representative results.

While international comparisons in education are often difficult due to cross-national differences in curriculum and population definitions (Bracey 2000), these concerns are less of an issue for this study, as the focus here is not a direct comparison of scores between countries, but rather an international comparison of within-country gender differences. Of more concern for this analysis is that TIMSS countries with information on high school students are primarily European; the non-European countries that are represented (Australia, Canada, Israel, New Zealand, South Africa, and the United States) are also predominantly Western. Although there is still a considerable amount of variation in national contexts, it is difficult to know how generalizable the findings are.

\section{Country-Level Data}

While some work analyzing cross-national variation relies on sorting countries into a typology (e.g., Esping-Andersen's [1990] three worlds of welfare capitalism), other work seeks to use country-level variables to model international variation. This study takes the latter approach, using a variety of country-level predictors to analyze variance in country-level gender differences in mathematics achievement. Analytically, this is similar to Fuwa's (2004) analysis of how macrolevel gender inequality shapes the gendered division of household labor. However, where Fuwa uses the UN Development Programme's Gender Empowerment Measure (GEM) to examine how gender inequality writ large affects the division of household labor, I am interested in examining what specific aspects of macrolevel gender inequality are related to gender differences in mathematics

\footnotetext{
${ }^{5}$ The mathematics literacy items in TIMSS are designed to assess students' knowledge, their ability to execute routine and complex procedures, and their problem-solving skills in the content areas of number sense, algebraic sense, and measurement and estimation (Martin and Kelly 1996). More information about the TIMSS data is available in Mullis et al. (2000).
} 
achievement. Thus, while the GEM combines factors like the percentage of women in parliament and the income gap between men and women into one measure, I combine variables like these into five different measures tapping different aspects of macrolevel gender inequality.

Data from the World Bank, the UN Statistics Department, the International Labour Organization, the World Values Survey, and the International Social Survey Programme are combined to create five variables: ${ }^{6}$

1. Education (ED) measures gender differences in education broadly. This measure is composed of variables such as differences in secondary enrollment and educational attainment. Higher values indicate that women are more advantaged (or less disadvantaged) in education.

2. Domesticity (DOM) measures the salience of children and home life considerations to women. This measure is composed of variables such as the amount of time women spend on housework and the importance of children to women's fulfillment. Higher values indicate that women are more likely to be viewed as strongly tied to the home and to children.

3. Labor force representation (REP) measures differences in the representation of men and women in the labor force. This measure is composed of variables such as the percentage of women who are in the labor force and the percentage of the labor force that is female. Higher values indicate that women are more highly represented in the labor force.

4. Labor force equality (EQ) measures equality in labor force position. This measure is composed of variables such as the percentage of managers who are female and attitudes about women's rights to a job. Higher values indicate that women are more advantaged (or less disadvantaged) in the labor market.

5. Status (STAT) measures differences between the general status of men and women. This measure is composed of variables such as the percentage of women in politics and gender differences in the age at first marriage. Higher values indicate that women have higher status in that society.

By design, the factor scores are on a standardized metric; all have a mean of zero and standard deviations between 1.17 and 1.59. This similarity

\footnotetext{
${ }^{6}$ These variables were created using information from 1995 wherever possible and from the nearest adjacent year when no information was available for 1995. Principle components were estimated using an eigendecomposition of the correlation matrix and are unrotated. Additional information about the creation of these variables is available upon request.
} 
American Journal of Sociology

allows for straightforward comparisons between the coefficients of the various factors. ${ }^{7}$ However, while it may be easy to grasp their importance vis-à-vis the other factors, factor scores can be somewhat obtuse. To ameliorate this shortcoming, table 1 contains information about the scores of countries on the five factors used in this analysis, as well as GEM, providing a sense for how the measures used here compare to GEM. Table 1 also allows us to understand more concretely what it means to be one unit apart on each of the five dimensions. For example, a one-unit difference in labor market representation roughly corresponds to the difference between the United States (1.12) and Norway (2.06).

\section{MODELING STRATEGY AND PRECEDENTS}

The public's interest in differences between men and women in extreme mathematical achievement was heightened following Harvard University president Larry Summers's (2005) speculation that the underrepresentation of women in the sciences could have a biological component. The ensuing controversy highlighted that sociology needs to better understand mathematics gender differences not just in the mean, but also at the extremes of the distribution.

There is some precedent for an extreme-oriented approach in the literature on gender differences in mathematics achievement. Several studies of gender differences in mathematics achievement report not only gender differences in the means and variances but also the ratios of girls to boys at the extremes of the distribution (e.g., Hedges and Nowell 1995; Stumpf and Stanley 1996; Nowell and Hedges 1998). More recent work on extreme achievement by Xie and Shauman (2003) has begun to model gender differences in representation at the distribution extremes using logistic regression. In addition to modeling differences in the composition of the extremes, it is also possible to measure differences between boys and girls at different percentiles using quantile regression. While quantile regression has a long history in economics, there is little work employing quantile regression to analyze differences in extreme educational achievement (but see Levin 2001).

This study makes use of both of logistic and quantile regression models to observe gender differences across the distribution of mathematics achievement. The logistic regression approach examines the likelihood of being above and beneath various cutpoints in the distribution. The quantile regression approach models the size of the differences between boys

\footnotetext{
${ }^{7}$ It is worth noting that the underlying metrics of the variables that go into these factor scores vary, so that we cannot really compare the metrics. Rather, we can compare the effects of moving one standard deviation in the different distributions.
} 
Gender and Math Achievement

TABLE 1

Country-Level Factor Scores and the United Nations Statistics Department's Gender Empowerment Measure (GEM)

\begin{tabular}{|c|c|c|c|c|c|c|}
\hline Country & $\mathrm{ED}$ & DOM & REP & EQ & STAT & GEM \\
\hline Australia .... & -.95 & -.11 & -.40 & .84 & .82 & .664 \\
\hline Austria $\ldots \ldots \ldots \ldots \ldots$ & -.76 & .93 & -.37 & -1.01 & .26 & .686 \\
\hline Canada $\ldots . . . . . \ldots \ldots$ & -.31 & -.19 & .82 & .38 & .12 & .720 \\
\hline Cyprus $\ldots \ldots \ldots \ldots \ldots$ & -.33 & -.13 & -2.34 & -1.40 & -2.75 & .379 \\
\hline Czech Republic ....... & -.94 & 1.75 & -.51 & -.36 & -1.54 & .527 \\
\hline Denmark ............. & 1.58 & .00 & 1.75 & -1.44 & .52 & .739 \\
\hline France $\ldots . . \ldots \ldots \ldots$ & -.28 & -.42 & -.04 & .46 & .64 & .489 \\
\hline Germany ............... & -1.56 & .82 & -.11 & .43 & .95 & 694 \\
\hline Hungary .............. & -.52 & 2.51 & -1.28 & .96 & -1.84 & .491 \\
\hline Iceland ..... & .82 & -1.18 & 2.54 & -1.18 & 2.37 & .723 \\
\hline Israel ...... & .43 & -2.27 & -.96 & .30 & -1.57 & .484 \\
\hline Italy $\ldots \ldots \ldots \ldots$ & -.91 & 1.56 & -3.76 & -.99 & -1.21 & .521 \\
\hline Lithuania ............ & .25 & 1.39 & .67 & 2.05 & -1.13 & .517 \\
\hline Netherlands $\ldots \ldots \ldots \ldots$ & -1.64 & -.79 & -.38 & -1.04 & 1.55 & 689 \\
\hline New Zealand ......... & 1.58 & -1.17 & .88 & .25 & 1.15 & .725 \\
\hline Norway ............... & .85 & -1.42 & 2.06 & -1.04 & 1.74 & .790 \\
\hline Russian Federation ... & -.31 & 2.37 & .04 & 2.38 & -1.91 & .426 \\
\hline Slovenia $\ldots \ldots \ldots \ldots \ldots$ & .35 & 1.17 & .10 & .75 & -1.78 & .475 \\
\hline South Africa ........... & .63 & -2.72 & -2.50 & -.62 & 1.23 & .531 \\
\hline Sweden $\ldots . . . \ldots$. & 4.60 & -.62 & 2.67 & -1.55 & 2.88 & .790 \\
\hline Switzerland ........... & -2.55 & .07 & .00 & -.09 & .47 & .654 \\
\hline United States .......... & -.03 & -1.53 & 1.12 & 1.93 & -.97 & .675 \\
\hline \multicolumn{7}{|l|}{ Overall: } \\
\hline Mean $\ldots . . . . . . . . .$. & .00 & .00 & .00 & .00 & .00 & .632 \\
\hline $\mathrm{SD} \ldots \ldots \ldots \ldots \ldots$ & 1.44 & 1.43 & 1.59 & 1.17 & 1.56 & .108 \\
\hline
\end{tabular}

NotE. - The GEM statistics listed are from 1995 except for Lithuania (1999) and Russia (2000).

and girls at various points in the distribution. In contrast to ordinary least squares (OLS) regression, which provides information about differences in conditional means, quantile regression can provide information regarding conditional differences at the 90th (or any other) percentile. Intuitively, the quantile regression results can be thought of as providing information about differences between scores at different points in the distribution, while the logistic regression results can be thought of as providing information about differences in the likelihood of being in different parts of the distribution. Thus, the quantile regression results from the 90th percentile report the difference between the 90th percentile of the boys' distribution and the 90th percentile of the girls' distribution, while the logistic regression results from the 90th percentile describe whether boys or girls are more likely to score at or above their country's 90th percentile. A more detailed discussion of these two approaches can be found in the appendix. 


\section{American Journal of Sociology}

In order to examine which country-level predictors are related to gender differences in extreme mathematical achievement, I estimate quantile and logistic regression models including gender, the five country-level predictors, and the interaction of gender and the country-level predictors. The interaction effects reveal the relative impact of that particular factor on gender differences in mathematics at the national level. All international models also control for per capita gross national income (GNI), and standard errors for these models are adjusted for country-level clustering using a sandwich estimator.

Before proceeding, a word of clarification is in order. Although model results are often used to make causal claims, this is not the emphasis here. Rather, the following cross-national models are better understood as stylized facts, a quantitative thick description designed to explore what kinds of factors covary with gender differences in mathematics achievement. The attempt here is thus not to make causal claims, but to examine what kinds of societies tend to have larger and smaller gender differences at the extremes of the distribution.

\section{ANALYSIS}

Much of the discussion surrounding genetic theories for gender differences in mathematical achievement revolves around basic descriptive statistics, especially differences in means and variances. I thus begin by revisiting these statistics in an international context and then proceed to examine statistics that more accurately describe the tails of the distribution. Finally, I present results from models of cross-national differences across the distribution.

\section{Basic Descriptive Statistics}

The conventional understanding against which I will be framing my findings argues that (1) mean differences in mathematics always favor males, evincing a biological basis; (2) males have a greater variance in mathematical ability, again evincing a biological basis; and (3) taken together, (1) and (2) indicate that there are more males in both tails of the distribution, but that this is especially true at the top of the distribution. I address the first two points in this section and the third point in the following section using logistic regression models.

Table 2 presents basic descriptive information from the countries in the TIMSS data and lists countries in descending order of the magnitude of their effects size (mean difference in standard deviation units, col. 7). Comparing the mean differences (col. 5) across countries reveals that mean 
Gender and Math Achievement

TABLE 2

Descriptive Statistics and Gender Differences in the Different Countries

\begin{tabular}{|c|c|c|c|c|c|c|c|}
\hline \multirow[b]{2}{*}{ COUNTRY } & \multirow[b]{2}{*}{$\begin{array}{l}N \\
(1)\end{array}$} & \multirow[b]{2}{*}{$\begin{array}{c}\text { \%FEMALE } \\
\text { (2) }\end{array}$} & \multicolumn{2}{|c|}{ Overall } & \multicolumn{2}{|c|}{$\begin{array}{c}\text { GENDER } \\
\text { DIFFERENCE }\end{array}$} & \multirow{2}{*}{$\begin{array}{c}\text { EFFECTS } \\
\text { SIZE } \\
(7)\end{array}$} \\
\hline & & & $\begin{array}{c}\text { Mean } \\
\text { (3) }\end{array}$ & $\begin{array}{l}\mathrm{SD} \\
(4)\end{array}$ & $\begin{array}{c}\text { Mean } \\
(5)\end{array}$ & $\begin{array}{l}\mathrm{SD} \\
(6)\end{array}$ & \\
\hline Netherlands ....... & 1,470 & .48 & 562 & 90 & $57 *$ & -11.3 & .63 \\
\hline Denmark ......... & 2,604 & .55 & 549 & 85 & $53^{*}$ & .8 & .62 \\
\hline Norway...$\ldots \ldots \ldots$ & 2,518 & .49 & 529 & 94 & $56^{*}$ & 10.3 & .60 \\
\hline Austria $\ldots \ldots \ldots \ldots$ & 1,779 & .62 & 515 & 75 & $42 *$ & 8.2 & .57 \\
\hline Czech Republic ... & 1,899 & .48 & 462 & 96 & $51^{*}$ & 10.5 & .53 \\
\hline Iceland $\ldots \ldots \ldots \ldots$ & 1,703 & .52 & 535 & 87 & $46^{*}$ & 3.5 & .53 \\
\hline France $\ldots \ldots \ldots \ldots$ & 1,590 & .53 & 525 & 78 & $40 *$ & 5.4 & .51 \\
\hline Slovenia $\ldots \ldots \ldots \ldots$ & 1,387 & .50 & 505 & 80 & $38^{*}$ & .7 & .48 \\
\hline Sweden $\ldots \ldots \ldots \ldots$ & 2,816 & .51 & 551 & 94 & $43^{*}$ & 13.2 & .45 \\
\hline Canada ............ & 4,832 & .53 & 519 & 88 & $34 *$ & 4.2 & .39 \\
\hline Switzerland ...... & 2,976 & .44 & 541 & 86 & $33^{*}$ & 1.4 & .38 \\
\hline Germany $\ldots . . . . .$. & 2,182 & .44 & 493 & 91 & $32 *$ & -4.7 & .36 \\
\hline Russian Fed. ...... & 2,289 & .62 & 470 & 85 & $28^{*}$ & 2.0 & .33 \\
\hline Italy .............. & 1,578 & .54 & 472 & 84 & $27 *$ & 6.8 & .33 \\
\hline Australia $\ldots \ldots \ldots$ & 1,844 & .58 & 522 & 97 & $29 *$ & 11.0 & .30 \\
\hline New Zealand ..... & 1,763 & .51 & 523 & 98 & $29 *$ & 9.2 & .29 \\
\hline Lithuania .......... & 2,887 & .65 & 468 & 84 & $23^{*}$ & -5.3 & .28 \\
\hline Israel .............. & 1,045 & .48 & 445 & 109 & $27^{*}$ & 3.3 & .25 \\
\hline South Africa ...... & 2,757 & .51 & 351 & 81 & $18^{*}$ & 3.4 & .22 \\
\hline Cyprus ............. & 473 & .55 & 440 & 69 & $14^{*}$ & 8.3 & .20 \\
\hline United States .... & 5,371 & .50 & 460 & 91 & $12 *$ & 7.8 & .13 \\
\hline Hungary ........... & 5,091 & .48 & 483 & 91 & 5 & 15.4 & .05 \\
\hline
\end{tabular}

Note.-Countries are sorted in descending order by their effects size (col. 7). For each country, col. 1 reports the number of observations; col. 2 reports the proportion of the sample that is female; col. 3 reports the mean mathematics literacy score; col. 4 reports the standard deviation of mathematics literacy; col. 5 reports the gender difference (male - female) in the mean of mathematics literacy; col. 6 reports the gender difference (male - female) in the standard deviation of mathematics literacy; col. 7 reports the effects size (mean difference in standard deviation units).

$$
* P<.05 \text {. }
$$

differences in all of the countries favor males, but also that there is a considerable amount of variation in the size of the mean differences that exist in different countries. ${ }^{8}$ Studies have argued that the prevalence of the male advantage implies that gender differences have an evolutionary origin (e.g., Geary 1996). This claim assumes that biological factors and their effects are constant, while sociological factors and their effects vary. However, by this reasoning, the considerable variation in the size of mean differences suggests that social factors are quite important. Mean differ-

${ }^{8}$ Other analyses not reported establish that the variation across countries is statistically significant. 


\section{American Journal of Sociology}

ences can thus be used to advance both social and biological theories for the origin of gender differences.

Table 2 also shows that the common assumption that males have greater variance in mathematics achievement is not universally true (col. 6). ${ }^{9}$ In three of the countries examined (Germany, Lithuania, and the Netherlands), women actually have greater variance than men, and among the countries that exhibit greater male variance the differences in variance range considerably in size. Thus, while claims about greater male variability are often used to support evolutionary arguments about gender differences in mathematics achievement (e.g., Geary 1998), these international findings call for caution.

I turn next to the question of representation in the distribution extremes. While work has been done using TIMSS and other surveys to examine gender differences in means and variability internationally (e.g., Steinkamp et al. 1985; Harnisch et al. 1986; Engelhard 1990; Feingold 1994; Riegle-Crumb 2005), there is no work investigating the gender differences at the distribution extremes internationally.

\section{Examining the Distribution Extremes}

\section{Logistic Regression Models}

Where the previous section examined claims about gender differences in means and variances internationally, this section examines gender differences in representation at the distribution extremes by estimating odds ratios for being female at different cutpoints in the distribution. In addition to providing basic information about the gender composition of the distribution tails in a variety of countries, examining the extremes directly also allows us to see whether the common assumption that the number of men increases the further out the tail of the distribution we look is true. $^{10}$

As in table 2, the countries in table 3 are sorted by their effects size to allow for a comparison of mean gender differences with the odds ratios for the different cutpoints in the distribution. Each column in table 3 reports estimates from a model at a different cutpoint. In the Czech Re-

\footnotetext{
${ }^{9}$ It is worth mentioning that although males are typically assumed to be more variable in mathematical abilities, Feingold (1994), in a cross-national metanalysis, also finds that differences in variability for mathematical and spatial abilities differ across countries, with males being more variable in some countries and females being more variable in others.

${ }^{10}$ It is worth noting that while logistic regression results are generally interpretable as odds ratios, because we are dealing with small odds and probabilities, these results can be interpreted as applying to probabilities, and because there are similar numbers of boys and girls, they can also be interpreted as applying to counts.
} 
Gender and Math Achievement

TABLE 3

Number of Girls in the Tails of the Distribution for Every Boy (Odds Ratios from Logistic Regressions)

\begin{tabular}{|c|c|c|c|c|c|c|c|c|}
\hline & $\begin{array}{c}\text { Effects } \\
\text { Size } \\
(1)\end{array}$ & $\begin{array}{c}\leq .10 \\
(2)\end{array}$ & $\begin{array}{c}\leq .25 \\
(3)\end{array}$ & $\begin{array}{l}\geq .50 \\
(4)\end{array}$ & $\begin{array}{c}\geq .75 \\
(5)\end{array}$ & $\begin{array}{c}\geq .90 \\
(6)\end{array}$ & $\begin{array}{c}.10 / .90 \chi^{2} \\
(7)\end{array}$ & $\begin{array}{c}.25 / .75 \chi^{2} \\
(8)\end{array}$ \\
\hline Netherlands $\ldots . . . . .$. & .63 & $6.25 *$ & $3.97 *$ & $.36 *$ & $.41^{*}$ & $.34 *$ & .01 & .00 \\
\hline Denmark & .62 & $3.27 *$ & $2.88^{*}$ & $.32 *$ & $.34 *$ & $.25 *$ & .36 & .84 \\
\hline Norway & .60 & $2.65^{*}$ & $2.47 *$ & $.34 *$ & $.32 *$ & $.22 *$ & .01 & .04 \\
\hline Austria & .57 & $1.96 *$ & $2.31^{*}$ & $.36 *$ & $.26^{*}$ & $.30 *$ & .03 & .00 \\
\hline Iceland & .53 & $2.82 *$ & $2.35 *$ & $.38^{*}$ & $.37 *$ & $.33 *$ & .76 & .28 \\
\hline Czech Republic ...... & .53 & $4.91^{*}$ & $2.70 *$ & $.47 *$ & $.43^{*}$ & $.24 *$ & .54 & .27 \\
\hline France $\ldots \ldots \ldots \ldots$ & .51 & $2.17 *$ & $2.12 *$ & $.40 *$ & $.37 *$ & $.35 *$ & .27 & .11 \\
\hline Slovenia ........ & .48 & $1.84^{*}$ & $2.25 *$ & .39 & $.37 *$ & $.43 *$ & .34 & .26 \\
\hline Sweden ....... & .45 & $1.69 *$ & $1.67 *$ & $.47 *$ & $.33 *$ & $.22 *$ & .00 & .00 \\
\hline Canada $\ldots . . . \ldots \ldots . . . .$. & .39 & $2.16^{*}$ & $1.79 *$ & $.59^{*}$ & $.51^{*}$ & $.29 *$ & .00 & .22 \\
\hline Switzerland ........... & .38 & $2.32 *$ & $1.89^{*}$ & $.59^{*}$ & $.48^{*}$ & $.37 *$ & .37 & .35 \\
\hline Germany .............. & .36 & $2.93^{*}$ & $1.69 *$ & $.60 *$ & $.57 *$ & $.56^{*}$ & .02 & .79 \\
\hline Russian Fed. ......... & .33 & $1.92 *$ & $1.46^{*}$ & $.57 *$ & $.52 *$ & $.60 *$ & .45 & .02 \\
\hline Italy $\ldots \ldots \ldots$ & .33 & $1.64 *$ & $1.82 *$ & $.61 *$ & $.48^{*}$ & $.43 *$ & .15 & .31 \\
\hline Australia & .30 & 1.44 & $1.52 *$ & $.62 *$ & $.47 *$ & $.43^{*}$ & .03 & .01 \\
\hline New Zealand ......... & .29 & 1.17 & $1.33^{*}$ & $.60 *$ & $.59^{*}$ & $.36^{*}$ & .00 & .06 \\
\hline Lithuania ..... & .28 & $2.78 *$ & $1.90 *$ & $.67 *$ & $.75^{*}$ & $.59^{*}$ & .01 & .00 \\
\hline Israel $\ldots \ldots \ldots$. & .25 & $1.35^{*}$ & $1.62 *$ & $.71^{*}$ & $.59^{*}$ & $.63 *$ & .57 & .81 \\
\hline South Africa ........... & .22 & $1.61^{*}$ & $1.46^{*}$ & $.61^{*}$ & $.56^{*}$ & $.61 *$ & .90 & .06 \\
\hline Cyprus ....... & .20 & 1.41 & 1.08 & $.69^{*}$ & $.62 *$ & .54 & .53 & .11 \\
\hline United States ......... & .13 & .95 & .95 & $.82 *$ & $.74^{*}$ & $.58 *$ & .00 & .00 \\
\hline Hungary............ & .05 & $.74^{*}$ & $.81^{*}$ & .99 & $.77 *$ & $.54 *$ & .00 & .00 \\
\hline
\end{tabular}

Note. - Countries are sorted in descending order by their effects size (mean difference in standard deviation units; col. 1). For each country, cols. 2-6 report the odds ratio of being female from a logistic regression model estimating the logged odds of scoring at or below the 10th percentile (col. 2), at or below the 25 th percentile (col. 3), at or above the 50th percentile (col. 4), at or above the 75 th percentile (col. 5), and at or above the 90th percentile (col. 6). Col. 7 reports the $P$-value from a log-likelihood $\chi^{2}$ test that the coefficients at the 10th and 90th percentiles are equivalent, and col. 8 reports the $P$ value from a $\log$-likelihood $\chi^{2}$ test that the coefficients at the 25 th and 75 th percentiles are equivalent. $* P<.05$.

public, for example, the results show that (1) for every boy in the bottom $10 \%$ of the distribution there are 4.91 girls (col. 2); (2) for every boy in the bottom $25 \%$ of the distribution there are 2.70 girls (col. 3); (3) for every boy above the median there are .47 girls (col. 4); (4) for every boy in the top $25 \%$ of the distribution there are .43 girls (col. 5); and (5) for every boy in the top $10 \%$ of the distribution there are .24 girls (col. 6).

Overall, I find that there is a male advantage in all of the countries, but that there is variation in the size of the gender differences. The international variation in the ratios of the different countries is statistically significant, indicating that environmental influences have an important effect. 
American Journal of Sociology

It is also worth noting that even a casual examination of table 3 shows that at both the top and bottom tails of the distribution, it is not the case that moving further out in the distribution tails always results in the presence of more boys. For example, in Austria, Israel, the Russian Federation, Slovenia, and South Africa, girls are better represented above the 90th percentile than they are above the 75th. This finding is important, as it contradicts the conventional wisdom that the underrepresentation of women is more severe further out in the upper tail. Table 3 also reports $P$-values from the log-likelihood chi-square tests of proportional odds (cols. 7-8), which test whether the ratios at the 10th (25th) and 90th (75th) percentiles are equivalent. ${ }^{11}$ The fact that so many of the $P$-values are less than .05 indicates that gender differences differ in magnitude at the top and bottom tails, so that simply comparing mean gender differences is misleading.

The results in table 3 can be summarized by four broad patterns of gender differences across the distribution. First, as in France, gender differences can be relatively stable in both tails of the distribution. Second, as in the Czech Republic, gender differences can grow more extreme in both tails the further out in the tail we look. Third, like New Zealand, countries can have gender differences that are stable at the bottom but grow more extreme at the top. Finally, in contrast to the third form, countries like Germany have stable gender differences at the top and gender differences that are larger further out in the bottom extreme of the distribution. It is noteworthy that what is largely absent is the pattern shown only by Hungary, where women are less likely to be at both extremes; from discussions of greater male variance one might assume that this would be the most common type.

\section{Quantile Regression Models}

Having examined gender differences in the composition of the distribution extremes, I next consider how the magnitude of gender differences varies across the distribution using quantile regression models. As it can be difficult to interpret the magnitude of differences in raw scores, the quantile regression model results presented here use logged mathematics score as their dependent variable. Logged score coefficients approximate percentage differences, so that a female coefficient of .01 indicates that girls' scores are roughly $1 \%$ higher than boys' scores at that same percentile. Table 4 reports results from five quantile regression models examining

\footnotetext{
${ }^{11}$ This is done using a log-likelihood chi-square test to compare the general ordered logistic (gologit) model to its ordered logistic counterpart and is discussed in greater detail by $\mathrm{Fu}(1998)$.
} 
Gender and Math Achievement

TABLE 4

The Effect of Being Female on Logged Mathematics Score at Different

QUANTILES

\begin{tabular}{|c|c|c|c|c|c|c|c|}
\hline & $\begin{array}{l}\text { OLS } \\
(1)\end{array}$ & $\begin{array}{l}.10 \\
(2)\end{array}$ & $\begin{array}{l}.25 \\
(3)\end{array}$ & $\begin{array}{l}.50 \\
(4)\end{array}$ & $\begin{array}{l}.75 \\
(5)\end{array}$ & $\begin{array}{l}.90 \\
(6)\end{array}$ & $\begin{array}{c}P \text { (ANOVA) } \\
(7)\end{array}$ \\
\hline Netherlands & $-.11 *$ & $-.16 *$ & $-.16^{*}$ & $-.11^{*}$ & $-.06 *$ & $-.06 *$ & .00 \\
\hline Denmark ........ & $-.10 *$ & $-.11 *$ & $-.11^{*}$ & $-.11^{*}$ & $-.08 *$ & $-.08 *$ & .00 \\
\hline Norway ............ & $-.10 *$ & $-.09 *$ & $-.11 *$ & $-.12 *$ & $-.11^{*}$ & $-.11 *$ & .28 \\
\hline Austria ... & $-.08 *$ & $-.06 *$ & $-.07 *$ & $-.11 *$ & $-.09 *$ & $-.07 *$ & .01 \\
\hline Czech Republic ... & $-.09 *$ & $-.12 *$ & $-.10 *$ & $-.10 *$ & $-.11^{*}$ & $-.13 *$ & .49 \\
\hline Iceland $\ldots$ & $-.11 *$ & $-.08 *$ & $-.08 *$ & $-.10 *$ & $-.09 *$ & $-.08 *$ & .36 \\
\hline France ....... & $-.08 *$ & $-.06 *$ & $-.08 *$ & $-.09 *$ & $-.08 *$ & $-.06 *$ & .38 \\
\hline Slovenia ...... & $-.08 *$ & $-.08 *$ & $-.10 *$ & $-.09 *$ & $-.07 *$ & $-.05 *$ & .17 \\
\hline Sweden $\ldots . . . \ldots \ldots$ & $-.08 *$ & $-.05 *$ & $-.07 *$ & $-.08 *$ & $-.10^{*}$ & $-.09 *$ & .03 \\
\hline Canada..... & $-.07 *$ & $-.07 *$ & $-.06^{*}$ & $-.06 *$ & $-.08^{*}$ & $-.08 *$ & .83 \\
\hline Switzerland .. & $-.06 *$ & $-.07 *$ & $-.07 *$ & $-.06^{*}$ & $-.06^{*}$ & $-.06^{*}$ & .81 \\
\hline Germany .... & $-.07 *$ & $-.12 *$ & $-.07 *$ & $-.05 *$ & $-.06^{*}$ & $-.04 *$ & .01 \\
\hline Russian Fed. ...... & $-.06 *$ & $-.05 *$ & $-.04 *$ & $-.08 *$ & $-.06^{*}$ & $-.04 *$ & .00 \\
\hline Italy $\ldots \ldots \ldots \ldots \ldots$ & $-.06 *$ & $-.05 *$ & $-.06^{*}$ & $-.05 *$ & $-.06^{*}$ & $-.06 *$ & .91 \\
\hline Australia .... & $-.05 *$ & -.04 & -.03 & $-.07 *$ & $-.07 *$ & $-.08 *$ & .23 \\
\hline New Zealand ..... & $-.05 *$ & -.01 & $-.05 *$ & $-.07 *$ & $-.05^{*}$ & $-.07 *$ & .20 \\
\hline Lithuania .......... & $-.05 *$ & $-.11^{*}$ & $-.07 *$ & $-.04^{*}$ & $-.03 *$ & $-.03 *$ & .00 \\
\hline Israel ....... & $-.07 *$ & $-.08 *$ & $-.08 *$ & $-.05 *$ & $-.06^{*}$ & -.03 & .29 \\
\hline South Africa ...... & $-.05 *$ & $-.03 *$ & $-.02 *$ & $-.04 *$ & $-.10 *$ & $-.10 *$ & .00 \\
\hline Cyprus ........... & -.03 & -.03 & -.01 & -.04 & -.04 & $-.05 *$ & .53 \\
\hline United States ..... & $-.02 *$ & .01 & .01 & -.02 & $-.04 *$ & $-.04 *$ & .05 \\
\hline Hungary ........... & -.00 & $.03 *$ & $.02 *$ & .00 & $-.03 *$ & $-.05 *$ & .00 \\
\hline
\end{tabular}

Note.-Countries are sorted in descending order by their effects size (mean difference in standard deviation units). For each country, col. 1 reports the effect of being female on logged mathematics literacy score from an OLS regression, and cols. 2-6 report the effect of being female on logged mathematics literacy score from quantile regression models estimated at the 10th percentile (col. 2), the 25 th percentile (col. 3), the 50th percentile (col. 4), the 75th percentile (col. 5), and the 90th percentile (col. 6). Col. 7 reports the $P$-value from an ANOVA test that the coefficients at the 10th, 25th, 50th, 75th, and 90th percentiles are equivalent.

$* P<.05$.

differences at the 10th, 25th, 50th, 75th, and 90th percentiles. As in table 3 , the countries in table 4 are sorted by their effects size. I include OLS results as a point of comparison; comparing results from OLS and quantile regression models provides a sense of what is missed by examining only the mean of the distribution.

By way of example, the results in table 4 indicate that in Hungary, (1) at the 10th and 25th percentiles, gender differences are significant and favor girls (cols. 2-3), (2) at the median, gender differences are insignificant (col. 4), and (3) at the 75th and 90th percentiles, gender differences are significant and favor boys (cols. 5-6). While the OLS coefficient in column 1 reports that the gender difference in Hungary is not statistically significant, the quantile regression results provide a more nuanced view, 
American Journal of Sociology

showing that the statistically significant female advantage at the bottom of the distribution and the statistically significant male advantage at the top of the distribution cancel each other out at the mean. In other countries the findings are less striking, but the differences across the distribution are equally important. In the United States, for example, the results indicate that boys score $2 \%$ higher than girls at the mean (col. 1), but the difference at the 90th percentile is twice that, at $4 \%$ (col. 6). Column 7 reports the $P$-value from an ANOVA test that the different quantiles have the same effects. This shows that of the 22 countries observed here, 10 have coefficients that vary significantly across the five points of the distribution observed, highlighting the importance of observing differences across the distribution and not looking exclusively at the middle of the distribution.

Examining the results in table 4, differences across the distribution again take four basic patterns. First, in roughly half of the countries, the male advantage is the same across the distribution. This pattern is exemplified by Switzerland, and in these countries the OLS results provide an accurate summary of gender differences. Second, in a few countries like the Netherlands and Lithuania, gender differences are found to be larger at the lower extreme of the distribution. Third, in several countries differences are larger at the top extreme. In some of these countries, like Sweden, the boys do better throughout the distribution but this advantage increases at the top, while in Hungary and the United States girls are found to do at least as well or better than boys at the bottom of the distribution but worse at the top. Finally, it is interesting to note that in Russia and Austria gender differences are actually larger in the middle of the distribution than at either extreme. That cross-national gender differences vary not only in magnitude but also in the pattern that they take across the distribution suggests that social factors have a substantial influence on gender differences in mathematics achievement.

\section{Modeling Cross-national Gender Differences across the Distribution}

Tables 3 and 4 document that gender differences vary across countries. I now expand on this finding by modeling how country-level factors are related to gender differences at different points in the distribution. To do this I include an individual-level dummy variable for being female, which is interacted with country-level predictors. By looking at the strength of the interaction effects I am able to see which of the country-level factors are most strongly associated with gender differences in mathematics achievement.

Table 5 presents logistic regression models examining the likelihood of being in certain parts of the distribution. Each column reports estimates 
Gender and Math Achievement

TABLE 5

Logistic Regression Coefficients Reporting the Effects of Country-Level Predictors on the Logged Odds of Scoring Above or Below Various Cutpoints, Net of Per Capita GNi

\begin{tabular}{|c|c|c|c|c|c|c|c|}
\hline & $\leq .05$ & $\leq .10$ & $\leq .25$ & $\geq .50$ & $\geq .75$ & $\geq .90$ & $\geq .95$ \\
\hline emale (FEM) & $\begin{array}{c}.63 \\
(5.47)\end{array}$ & $\begin{array}{c}.63 \\
(6.96)\end{array}$ & $\begin{array}{c}.53 \\
(8.21)\end{array}$ & $\begin{array}{c}-.60 \\
(12.27)\end{array}$ & $\begin{array}{c}-.72 \\
(18.12)\end{array}$ & $\begin{array}{c}-.96 \\
(20.91)\end{array}$ & $\begin{array}{l}-1.06 \\
(16.72)\end{array}$ \\
\hline Education (ED) . & $\begin{array}{c}.11 \\
(2.01)\end{array}$ & $\begin{array}{c}.11 \\
(2.65)\end{array}$ & $\begin{array}{c}.06 \\
(1.94)\end{array}$ & $\begin{array}{c}-.01 \\
(.56)\end{array}$ & $\begin{array}{c}-.01 \\
(.60)\end{array}$ & $\begin{array}{c}-.01 \\
(.86)\end{array}$ & $\begin{array}{r}-.01 \\
(.47)\end{array}$ \\
\hline Domesticity (DOM) & $\begin{array}{c}-.02 \\
(.35)\end{array}$ & $\begin{array}{c}-.02 \\
(.29)\end{array}$ & $\begin{array}{c}-.01 \\
(.14)\end{array}$ & $\begin{array}{c}-.01 \\
(.19)\end{array}$ & $\begin{array}{l}.01 \\
(.32)\end{array}$ & $\begin{array}{l}.01 \\
(.45)\end{array}$ & $\begin{array}{l}.01 \\
(.46)\end{array}$ \\
\hline Representation (REP) ... & $\begin{array}{l}-.12 \\
(2.60)\end{array}$ & $\begin{array}{l}-.10 \\
(2.56)\end{array}$ & $\begin{array}{l}-.07 \\
(2.80)\end{array}$ & $\begin{array}{c}.05 \\
(2.98)\end{array}$ & $\begin{array}{c}.03 \\
(2.45)\end{array}$ & $\begin{array}{c}.05 \\
(3.15)\end{array}$ & $\begin{array}{c}.07 \\
(3.99)\end{array}$ \\
\hline Equality (EQ) & $\begin{array}{c}.13 \\
(1.58)\end{array}$ & $\begin{array}{c}.17 \\
(2.44)\end{array}$ & $\begin{array}{c}.15 \\
(3.34)\end{array}$ & $\begin{array}{l}-.11 \\
(3.62)\end{array}$ & $\begin{array}{l}-.09 \\
(3.24)\end{array}$ & $\begin{array}{l}-.10 \\
(4.18)\end{array}$ & $\begin{array}{l}-.08 \\
(3.24)\end{array}$ \\
\hline Status (STAT & $\begin{array}{l}.00 \\
(.02)\end{array}$ & $\begin{array}{c}.00 \\
(.03)\end{array}$ & $\begin{array}{c}.01 \\
(.34)\end{array}$ & $\begin{array}{r}-.02 \\
(.66)\end{array}$ & $\begin{array}{c}.00 \\
(.01)\end{array}$ & $\begin{array}{r}-.02 \\
(.80)\end{array}$ & $\begin{array}{l}-.04 \\
(1.43)\end{array}$ \\
\hline FEM & $\begin{array}{l}-.18 \\
(2.24)\end{array}$ & $\begin{array}{l}-.17 \\
(2.89)\end{array}$ & $\begin{array}{l}-.11 \\
(2.33)\end{array}$ & $\begin{array}{l}.03 \\
(.78)\end{array}$ & $\begin{array}{c}.02 \\
(1.14)\end{array}$ & $\begin{array}{c}.03 \\
(1.28)\end{array}$ & $\begin{array}{l}.03 \\
(.67)\end{array}$ \\
\hline $\mathrm{FEM} \times \mathrm{DOM}$ & $\begin{array}{c}.03 \\
(.32)\end{array}$ & $\begin{array}{c}.03 \\
(.27)\end{array}$ & $\begin{array}{c}.01 \\
(.13)\end{array}$ & $\begin{array}{c}.01 \\
(.21)\end{array}$ & $\begin{array}{c}-.02 \\
(.51)\end{array}$ & $\begin{array}{c}-.01 \\
(.30)\end{array}$ & $\begin{array}{r}-.01 \\
(.15)\end{array}$ \\
\hline $\mathrm{FEM} \times \mathrm{REP}$ & $\begin{array}{c}.19 \\
(2.48)\end{array}$ & $\begin{array}{c}.15 \\
(2.40)\end{array}$ & $\begin{array}{c}.11 \\
(2.77)\end{array}$ & $\begin{array}{l}-.10 \\
(3.12)\end{array}$ & $\begin{array}{l}-.07 \\
(3.14)\end{array}$ & $\begin{array}{l}-.14 \\
(4.16)\end{array}$ & $\begin{array}{l}-.21 \\
(4.51)\end{array}$ \\
\hline $\mathrm{FEM} \times \mathrm{EQ}$ & $\begin{array}{l}-.20 \\
(1.54)\end{array}$ & $\begin{array}{l}-.26 \\
(2.35)\end{array}$ & $\begin{array}{l}-.24 \\
(3.34)\end{array}$ & $\begin{array}{c}.21 \\
(4.07)\end{array}$ & $\begin{array}{c}.20 \\
(4.08)\end{array}$ & $\begin{array}{c}.29 \\
(5.19)\end{array}$ & $\begin{array}{c}.28 \\
(4.01)\end{array}$ \\
\hline FEM $\times$ STAT & $\begin{array}{c}.00 \\
(.03)\end{array}$ & $\begin{array}{l}.01 \\
(.15)\end{array}$ & $\begin{array}{c}-.01 \\
(.17)\end{array}$ & $\begin{array}{l}.03 \\
(.62)\end{array}$ & $\begin{array}{l}.00 \\
(.07)\end{array}$ & $\begin{array}{c}.08 \\
(1.08)\end{array}$ & $\begin{array}{c}.14 \\
(1.47)\end{array}$ \\
\hline Constant & $\begin{array}{l}-3.32 \\
(44.22)\end{array}$ & $\begin{array}{l}-2.57 \\
(44.03)\end{array}$ & $\begin{array}{l}-1.40 \\
(35.31)\end{array}$ & $\begin{array}{c}.33 \\
(10.89)\end{array}$ & $\begin{array}{c}-.74 \\
(28.46)\end{array}$ & $\begin{array}{l}-1.77 \\
(62.19)\end{array}$ & $\begin{array}{l}-2.31 \\
(71.91)\end{array}$ \\
\hline
\end{tabular}

Note. $-N$ observations $=54,965$. Numbers in parentheses are the absolute value of $z$ statistics. Each column reports the results from a model estimated at a different cutpoint. Female (FEM) is a dummy variable for being female, and education (ED), domesticity (DOM), representation (REP), equality (EQ), and status (STAT) are national-level factor scores. The coefficients for the interactions between FEM and the national-level factors are reported as FEM $\times$ [the respective factor]. Per capita GNI is included as a control variable.

from a different cutpoint, and all models contain the same independent variables. These models estimate the likelihood of being at or below the 5 th, 10th, and 25th percentiles and being at or above the 50th, 75th, 90th, and 95th percentiles. Given that we are modeling the likelihood of being above and below certain cutpoints, the sign on the coefficients changes when we switch between looking beneath those points to looking above those points. For example, the positive coefficient for "female" at .05 indicates that women are overrepresented relative to men in the bottom tail of the distribution, while the negative coefficient for "female" at .95 indicates that women are underrepresented relative to men at the top of the distribution. 
American Journal of Sociology

Examining the interaction effects in table 5 reveals that educational inequality affects the bottom of the distribution more than the top and that labor force representation and inequality both influence gender differences throughout the distribution. Thus, at the bottom of the distribution, country-level differences in education, labor force representation, and labor force equality are important, while at the middle and top of the distribution only labor force representation and equality seem to matter.

Looking at the direction of the interaction effects, we find that the effects are generally in the expected direction. Countries with smaller female disadvantages in mathematics achievement tend to be countries where (1) women are less associated with home and children, (2) there is greater educational gender equality, (3) there is little gender inequality in the labor force, and (4) women have higher status in general. Interestingly, the effect of the representation of women in the labor force is such that countries with greater female representation tend to have larger gender differences in mathematics achievement. While this is somewhat counterintuitive, it seems plausible that countries with greater female representation in the labor force offer more opportunities for women in femaledominated nontechnical sectors. ${ }^{12}$

Table 6 translates the results from the logistic regression models in table 5 into predicted probabilities that men and women will score in the top $25 \%, 10 \%$, and $5 \%$ of their country's distribution, in a context where all variables except labor market equality are held at their means. Predicted probabilities are reported for labor market equality levels at the mean (average), at one unit above the mean (egalitarian), and at one unit below the mean (inegalitarian). Referring back to table 1, this roughly corresponds to countries with labor market equality levels similar to those of Austria (inegalitarian, 1.01 units below the mean), Switzerland (average, at the mean), and Hungary (egalitarian, .96 units above the mean). Thus, for example, holding the other factors at the mean, we would expect that in a country with a degree of labor market equality similar to Austria, $14.4 \%$ of the men would be in the top $10 \%$ of the distribution, compared to only $4.8 \%$ of the women. By contrast, in a country with labor market equality similar to Hungary, we would expect $11.7 \%$ of the men to be in the top $10 \%$, along with $6.3 \%$ of the women. While the differences remain

\footnotetext{
${ }^{12}$ Other analyses (not shown) find that, in this sample, countries with greater female representation also tend to have higher degrees of occupational gender segregation in the labor market. It is also worth noting that this counterintuitive effect of labor market representation is net of the other factors in the model and that the sample of countries includes only European and other Western countries.
} 
Gender and Math Achievement

TABLE 6

Predicted Probabilities for Men and Women's Mathematics in

Contexts with Varying Degrees of Equality and All Other

Variables Held Constant at the Mean

\begin{tabular}{|c|c|c|c|}
\hline \multirow{2}{*}{$\begin{array}{c}\text { Probability of BeING } \\
\text { IN ToP }\end{array}$} & \multicolumn{3}{|c|}{ Labor Market Equality of Country } \\
\hline & Inegalitarian & Average & Egalitarian \\
\hline \multicolumn{4}{|l|}{$25 \%:$} \\
\hline Male & .325 & .301 & .278 \\
\hline Female & .161 & .175 & .190 \\
\hline Difference & .164 & .126 & .089 \\
\hline \multicolumn{4}{|l|}{$10 \%:$} \\
\hline Male & .144 & .130 & .117 \\
\hline Female $\ldots \ldots \ldots \ldots \ldots \ldots$ & .048 & .055 & .063 \\
\hline Difference $\ldots \ldots \ldots \ldots \ldots$ & .096 & .075 & .053 \\
\hline \multicolumn{4}{|l|}{$5 \%:$} \\
\hline Male & .089 & .080 & .072 \\
\hline Female $\ldots \ldots \ldots \ldots \ldots \ldots$ & .025 & .030 & .035 \\
\hline Difference $\ldots \ldots \ldots \ldots \ldots$ & .064 & .050 & .037 \\
\hline
\end{tabular}

substantial even in the egalitarian countries, they are considerably smaller than in their inegalitarian counterparts.

Table 7 presents results from quantile regression models of mathematics achievement estimated at various quantiles throughout the distribution. As in table 5, each column reports the results for a model estimated at a different point in the distribution, and the interaction effects provide a sense of how relevant the various country-level factors are to gender differences. Looking at the interaction effects we find that education and domesticity impact gender differences only at the bottom of the distribution, status has an effect only at the top, and labor force representation and equality are related to gender differences across the distribution. From a distributional perspective this means that at the bottom of the distribution there is no effect of status, but all of the other factors are pertinent (though the effect of domesticity is relatively small); in the middle of the distribution, only labor force related factors seem to be relevant; and at the top of the distribution, labor force factors and general status are germane.

How should we interpret the evidence from tables 5, 6, and 7? The first and most obvious point is that labor force considerations (representation and equality) are closely related to gender differences in mathematics. Net of other factors, higher levels of female labor force participation tend to exacerbate the female disadvantage in mathematics, while higher levels of gender equality tend to play a mitigating role. The effects of these two factors are visible throughout the distribution. Second, gender 
American Journal of Sociology

TABLE 7

Quantile Regression Models Reporting the Effects of Country-Level Predictors on logged Score at Various Percentiles, Net of Per Capita GNi

\begin{tabular}{|c|c|c|c|c|c|c|c|}
\hline & .05 & .10 & .25 & .50 & .75 & .90 & .95 \\
\hline Female (FEM). & $\begin{array}{c}-.058 \\
(22.79)\end{array}$ & $\begin{array}{c}-.048 \\
(11.32)\end{array}$ & $\begin{array}{l}-.057 \\
(9.27)\end{array}$ & $\begin{array}{l}-.069 \\
(8.84)\end{array}$ & $\begin{array}{r}-.073 \\
(13.97)\end{array}$ & $\begin{array}{c}-.069 \\
(23.30)\end{array}$ & $\begin{array}{c}-.068 \\
(40.48)\end{array}$ \\
\hline Education (ED) & $\begin{array}{l}-.018 \\
(6.52)\end{array}$ & $\begin{array}{l}-.015 \\
(2.75)\end{array}$ & $\begin{array}{l}-.012 \\
(1.11)\end{array}$ & $\begin{array}{c}-.009 \\
(.66)\end{array}$ & $\begin{array}{r}-.007 \\
(.74)\end{array}$ & $\begin{array}{l}-.006 \\
(1.20)\end{array}$ & $\begin{array}{l}-.004 \\
(1.37)\end{array}$ \\
\hline Domesticity (DOM) ..... & $\begin{array}{r}.052 \\
(17.81)\end{array}$ & $\begin{array}{r}.053 \\
(9.40)\end{array}$ & $\begin{array}{r}.055 \\
(3.65)\end{array}$ & $\begin{array}{r}.049 \\
(2.08)\end{array}$ & $\begin{array}{r}.027 \\
(1.33)\end{array}$ & $\begin{array}{r}.013 \\
(1.07)\end{array}$ & $\begin{array}{r}.008 \\
(1.09)\end{array}$ \\
\hline Representation (REP) & $\begin{array}{r}.044 \\
(15.55)\end{array}$ & $\begin{array}{r}.045 \\
(7.58)\end{array}$ & $\begin{array}{r}.045 \\
(3.42)\end{array}$ & $\begin{array}{r}.044 \\
(2.52)\end{array}$ & $\begin{array}{r}.031 \\
(2.08)\end{array}$ & $\begin{array}{r}.025 \\
(2.75)\end{array}$ & $\begin{array}{r}.016 \\
(2.89)\end{array}$ \\
\hline Equality (EQ) . & $\begin{array}{l}-.037 \\
(8.25)\end{array}$ & $\begin{array}{l}-.039 \\
(4.26)\end{array}$ & $\begin{array}{l}-.033 \\
(1.94)\end{array}$ & $\begin{array}{l}-.032 \\
(1.47)\end{array}$ & $\begin{array}{l}-.027 \\
(1.66)\end{array}$ & $\begin{array}{l}-.024 \\
(2.66)\end{array}$ & $\begin{array}{l}-.022 \\
(3.90)\end{array}$ \\
\hline Status (STAT) & $\begin{array}{r}.019 \\
(4.74)\end{array}$ & $\begin{array}{r}.014 \\
(1.75)\end{array}$ & $\begin{array}{l}.013 \\
(.77)\end{array}$ & $\begin{array}{l}.005 \\
(.19)\end{array}$ & $\begin{array}{l}.007 \\
(.31)\end{array}$ & $\begin{array}{l}.006 \\
(.50)\end{array}$ & $\begin{array}{l}.007 \\
(.92)\end{array}$ \\
\hline $\mathrm{FEM} \times \mathrm{ED}$ & $\begin{array}{r}.014 \\
(8.17)\end{array}$ & $\begin{array}{r}.009 \\
(3.25)\end{array}$ & $\begin{array}{r}.007 \\
(1.80)\end{array}$ & $\begin{array}{l}.001 \\
(.24)\end{array}$ & $\begin{array}{c}-.003 \\
(.98)\end{array}$ & $\begin{array}{l}.000 \\
(.14)\end{array}$ & $\begin{array}{r}-.001 \\
(.67)\end{array}$ \\
\hline $\mathrm{FEM} \times \mathrm{DOM}$ & $\begin{array}{l}-.006 \\
(2.17)\end{array}$ & $\begin{array}{c}-.004 \\
(.76)\end{array}$ & $\begin{array}{l}.004 \\
(.52)\end{array}$ & $\begin{array}{l}.006 \\
(.69)\end{array}$ & $\begin{array}{r}.007 \\
(1.29)\end{array}$ & $\begin{array}{l}.001 \\
(.34)\end{array}$ & $\begin{array}{r}.003 \\
(1.82)\end{array}$ \\
\hline $\mathrm{FEM} \times \mathrm{REP}$ & $\begin{array}{l}-.015 \\
(8.36)\end{array}$ & $\begin{array}{l}-.013 \\
(4.23)\end{array}$ & $\begin{array}{l}-.015 \\
(3.95)\end{array}$ & $\begin{array}{l}-.008 \\
(2.05)\end{array}$ & $\begin{array}{r}-.002 \\
(.63)\end{array}$ & $\begin{array}{l}-.007 \\
(3.02)\end{array}$ & $\begin{array}{l}-.005 \\
(2.52)\end{array}$ \\
\hline $\mathrm{FEM} \times \mathrm{EQ}$ & $\begin{array}{l}.020 \\
(7.79)\end{array}$ & $\begin{array}{r}.025 \\
(4.76)\end{array}$ & $\begin{array}{r}.026 \\
(3.61)\end{array}$ & $\begin{array}{l}.024 \\
(2.44)\end{array}$ & $\begin{array}{r}.020 \\
(3.02)\end{array}$ & $\begin{array}{r}.016 \\
(4.29)\end{array}$ & $\begin{array}{r}.013 \\
(5.69)\end{array}$ \\
\hline $\mathrm{FEM} \times \mathrm{STAT}$ & $\begin{array}{c}-.001 \\
(.30)\end{array}$ & $\begin{array}{l}.004 \\
(.83)\end{array}$ & $\begin{array}{r}.009 \\
(1.14)\end{array}$ & $\begin{array}{l}.010 \\
(.92)\end{array}$ & $\begin{array}{r}.010 \\
(1.31)\end{array}$ & $\begin{array}{r}.010 \\
(2.32)\end{array}$ & $\begin{array}{r}.010 \\
(3.86)\end{array}$ \\
\hline Constant & $\begin{array}{r}5.820 \\
(652.95)\end{array}$ & $\begin{array}{r}5.880 \\
(308.21)\end{array}$ & $\begin{array}{r}5.987 \\
(140.73)\end{array}$ & $\begin{array}{r}6.134 \\
(97.07)\end{array}$ & $\begin{array}{r}6.315 \\
(123.03)\end{array}$ & $\begin{array}{r}6.446 \\
(224.66)\end{array}$ & $\begin{array}{r}6.504 \\
(386.26)\end{array}$ \\
\hline
\end{tabular}

Note. $-N$ observations $=54,965$. Numbers in parentheses are absolute value of $t$ statistics. Each column reports the results from a model at a different quantile. Female (FEM) is a dummy variable for being female, and education (ED), domesticity (DOM), representation (REP), equality (EQ), and status (STAT) are national-level factor scores. The coefficients for the interactions between FEM and the national-level factors are reported as FEM $\times$ [the respective factor]. Per capita GNI is included as a control variable.

equity in education writ large seems to matter most for gender differences in mathematics achievement at the bottom of the distribution. Third, the effect of status is found to matter only at the top of the distribution and is more closely related to differences in the scores at the top than differences in the composition. Finally, differences in ideologies concerning the importance of home and children for women do not track well with crossnational variation in gender differences in mathematics achievement.

If we think more specifically about mathematics achievement at the top of the distribution, these results are interesting both for what factors they suggest are important and also for what factors they suggest are not important. For example, finding that gender differences at the top of the mathematics distribution are associated with labor market factors, but 
Gender and Math Achievement

not with broader educational equality, suggests that gender differences in mathematics achievement are more closely linked to the labor market than to these broader educational considerations. Similarly, the finding that differences in the relative status of men and women are linked to gender differences at the top end of the mathematics distribution, but that ideologies regarding women and children are not, suggests that gender differences in status influence mathematics achievement at the top of the distribution more than ideologies about the importance of children to women. The finding that labor market factors matter suggests that students make decisions about their education with an awareness of the types of labor market opportunities available to them, and the findings for status suggest that national-level gender differences in status play a role in creating the framework within which status characteristics effects appear. Taken together, the results for labor market factors and the relative status of women in a society highlight how national contexts define the realm of possibilities for boys and girls in high school.

\section{DISCUSSION}

Currently, sociological research on gender differences in mathematics achievement largely ignores genetic and other biological considerations. This is unfortunate, as research on the potential role of social and biological factors in creating gender differences in mathematics achievement not only provides a more complete understanding of these differences, but also has important consequences for the achievement of women in mathematics and the sciences more broadly. In a recent experiment, DarNimrod and Heine (2006) find that telling girls that gender differences in mathematics achievement are caused by genetic differences lowers their mathematics performance, while attributing gender differences to experiential factors does not. This finding underscores the importance of taking genetic factors seriously and engaging in research that is both informed by and responsive to genetic considerations. I seek to do this by drawing on the literature on genetic considerations in two ways: first, by examining variability and other measures of differences throughout the distribution, and second, through adopting an international scope. As genetic theories for gender differences in mathematics achievement often focus either on the variability of mathematics achievement (e.g., Geary 1998), or on high achievement explicitly (e.g., Thomas and Kail 1991), this study moves beyond the mean-based measures of gender differences and examines differences throughout the distribution. Second, this study draws on work by Benbow (1988) and Geary (1996) in suggesting that the genetic component of gender should be relatively invariant across countries and in 
American Journal of Sociology

using international comparisons to think about the roles of biological and social factors.

This approach allows us to learn not only about the potential role of genetic factors but also about how macrolevel social factors affect gender differences in mathematics achievement. The main findings can be summarized as follows:

1. Men have higher mean scores in all of the countries examined, but the size of these differences between men and women varies considerably, evincing the importance of environmental factors.

2. Men are not found to be universally more variable in mathematics achievement, providing an important qualifier to evolutionary psychology's arguments for greater male variability.

3. Gender differences within a given country vary across the distribution, taking different patterns in different countries, so that it is important to use methods that can examine gender differences at the distribution extremes.

4. General social status and labor market differences are the macrolevel factors that are most strongly related to gender differences at the upper tail of the distribution in mathematics achievement.

Of these findings, two are particularly novel and especially surprising (points 2 and 3). First, there is no reason to believe that the patterns that gender differences take across countries would differ. That is, while there is some work suggesting that gender differences in mathematics achievement are larger at the top of the distribution, there is no research that suggests that in some countries we would expect larger gender differences at the top of the distribution and in other countries larger differences at the bottom. Second, while it is often assumed that males have greater variability in mathematics achievement and are overrepresented at both tails of the distribution, I find that in some countries women have greater variability and that in most countries men are actually underrepresented at bottom of the distribution. In proceeding, I next address the implications of my findings for genetic theories surrounding gender differences in mathematics achievement and then conclude by suggesting avenues for future research.

Cross-national Variation and Genetic Factors

International comparisons provide a useful perspective through which to examine biological and social theories regarding gender differences in mathematics achievement. Finding consistent gender differences around the world would indicate either that differences have a biological basis or that gender socialization is remarkably constant. On the other hand, finding that differences vary widely (as they do) indicates that whatever 
biological factors may be implicated, gender differences are also shaped by country-specific socialization processes. The cross-national variation documented in this study also has more specific implications for genetic theories about gender differences in mathematics achievement. For example, the finding that there are countries with greater female variability is difficult for the sex-linked recessive gene theory to accommodate. It is of course possible that sex-linked recessive gene hypothesis is accurate and that other biological or social factors are responsible for the greater female variance in these countries. However, even if this were the case, this finding suggests that the sex-linked recessive gene theory as it currently stands is in need of substantial augmentation before it is useful in explaining cross-national variation.

Of more interest are recent suggestions that evolution has left men more vulnerable to environmental influences, and hence more variable, than women (Geary 1998). This theory can better accommodate international variation, as it provides an explicit role for social factors. Even so, it is still difficult to envision a scenario in which greater male sensitivity to environmental conditions could result in greater male variance in some countries and greater female variance in others. Thus, even where genetic theories incorporate environmental variation, and could accommodate international variation in gender differences, additional work is needed in order to explain the pattern of international results described here.

Findings from international data can also be used to assign an upper bound to the role of strictly genetic factors and a lower bound to the amount of the gender gap that is influenced by social considerations. ${ }^{13}$ Although the impossibility of isolating biological and social factors makes it difficult to discuss their relative importance, making a few assumptions allows us to draw some conclusions about this question. To begin, we assume that genetic factors impacting gender differences are similar across different countries, but that social factors may vary. Using the United States as an example, we next add the assumption that the current social structure in the United States does not aid women's mathematics achievement more than men's. These assumptions allow us to conclude that any gender differences in mathematics caused strictly by genetic factors cannot be larger than the gender difference in the United States. Thus, by comparing the gender difference in the United States to gender differences in other countries, we can get some purchase on the relevance of social

\footnotetext{
${ }^{13}$ Again, as was noted earlier, this kind of strict duality is not particularly helpful, as it is possible that there exist considerations such as diet-hormone interactions and other similar factors with biological components. However, as these interactions can be substantially altered through social means, they can be thought of as primarily social factors.
} 


\section{American Journal of Sociology}

considerations in those countries. For example, table 4 reveals that in the United States the gender difference at the 90th percentile is -.04 , while in the Czech Republic it is -.13 . This suggests that at least two-thirds of the gender gap at the 90th percentile in the Czech Republic is due to social considerations. As the United States tends to have one of the smaller gender differences, this exercise is less informative for looking at gender differences in the United States. However, if we assume that social factors in Hungary do not aid women's mathematics achievement, then looking at the mean differences of the United States and Hungary reported in table 2 indicates that at least $58 \%$ of the mean difference found in the United States is due to social factors.

Thinking about international results in terms of partitioning genetic and social variance raises an interesting possibility: the degree to which gender differences in mathematics achievement can be attributed to genetic factors might vary based on societal context. While researchers readily admit that estimates of the heritability of intelligence likely vary based on environmental factors such as neglect, the results here suggest that they might vary by national context as well. ${ }^{14}$ Along these lines, Sato et al. (2004) note that Japanese estimates of intelligence heritability are typically smaller than those of Western studies and suggest country-level differences as one explanation. Thus, where previous work looking at gene-environment interactions focuses on microlevel contexts, it is possible that broader macrolevel contextual factors could play a similar role. This is interesting, among other reasons, because it recasts genetic factors so that even the percentage of variance accounted for by genetic factors could be influenced by macrolevel environmental factors.

\section{Conclusion}

While the international variation documented in this study highlights the continued relevance of social factors, given the multitude of biological processes required to take a mathematics test (e.g., reading the problem, thinking of the solution, recording the answer), it is hard to imagine that differences are not at some level biologically mediated. Thus, as future research increases our understanding of the biological processes involved in mathematics achievement, it is important to remember the ways in which these processes are shaped by social factors. To that end, this study

\footnotetext{
${ }^{14}$ If the proportion of the gender gap attributable to genetic considerations does not vary by national context, then the highest lower bound found in any country for the amount of the gender gap that could be social can be extended to all countries. For example, at the 90th percentile we see that in the Czech Republic at least two-thirds of the gap is social, so we could say that this must hold true across countries.
} 
Gender and Math Achievement

suggests that future research would do well to examine the influence of macrosocial contexts; in particular, research examining how macrolevel factors interact with microlevel factors (e.g., parent, teacher, and peer effects) to form gender inequality across the distribution would be informative.

In addition, the international perspective is potentially helpful in increasing our understanding of how biological and social factors interact more broadly. For example, studies of gender differences in cognitive abilities might examine how national differences in factors like diet interact with considerations such as hormones and iron deficiency to impact gender differences. Or in the case of genetics, there is little international research on the heritability of cognitive abilities (but see Wright et al. 2001), and work that systematically examines how heritability estimates vary internationally would be of great interest. Similarly, while its complexity should not be underestimated, research attempting to identify combinations of genes contributing to intelligence (e.g., Plomin and Craig 2001) and how they interact with environmental factors could also benefit from a cross-national perspective.

\section{APPENDIX A}

\section{Methodological Appendix}

Logistic Regression Models

A series of logistic regression models are estimated to provide information about how being female affects the odds ratios for being at or above and at or below different cutpoints in the distribution. The dependent variables are dummy variables indicating whether a given observation is at or further out in the tail than a particular cutpoint in that country (e.g., less than or equal to the 25 th percentile, or greater than or equal to the 90th percentile). Logistic regression results are often difficult to interpret intuitively, but in this context they have a relatively straightforward interpretation. While it is generally incorrect to interpret odds ratios as probability ratios, for small probabilities, such as those in the distribution extremes, the odds (and odds ratios) approximate the underlying probabilities (and probability ratios). Thus, while at the middle of the distribution this is not a good interpretation, it does aid in understanding extreme differences. Probability ratios can be interpreted as comparing the relative likelihoods of extreme scoring among boys and girls and are independent of discrepancies in their representation in the underlying population. When there are similar numbers of boys and girls, these probability ratios can be thought of as count ratios-that is, the ratio of the actual numbers of boys and girls. The logistic regression results in this 


\section{American Journal of Sociology}

study can thus be thought of in terms of the number of girls per boy above and below different cutpoints in the distribution.

More formally, the logistic regression models in this paper take the form:

$$
\ln \left(\frac{p_{i}}{1-p_{i}}\right)=X_{i} \beta+\epsilon_{i}
$$

where $X_{i}$ includes the independent variables, in this case the constant and a dummy variable for being female as well as any control variables and interactions introduced into the model. $p_{i}$ is the probability that student $i$ has $Y_{i}=1$, where $Y_{i}$ is a dummy variable that is equal to 1 if an observation is at least as far out in the tail of the distribution as the cutpoint, and zero otherwise. This model is estimated for a series of $Y_{i}$ with different cutpoints, providing information about the likelihood of being above or below various points in the distribution. For example, the logistic regression model analyzing the 25 th percentile would model the logged odds that a student scored at or below the 25 th percentile in his or her country's distribution, while the model examining the 75 th percentile models the logged odds of a student's being at or above the 75th percentile in his or her country's distribution.

\section{Quantile Regression Models}

The quantile regression models estimated in this article take the standard form:

$$
Y_{i}=X_{i} \beta+\epsilon_{i},
$$

where $Y_{i}$ is the mathematics score for student $i$, and $X_{i}$ includes the independent variables. As laid out in Koenker and Basset (1978), this model can be estimated at the $\theta$ th quantile by minimizing equation (A3):

$$
\min _{\beta}\left[\sum_{\left\{i \mid y_{i} \geq X_{i} \beta\right\}} \theta\left|Y_{i}-X_{i} \beta\right|+\sum_{\left\{i \mid y_{i}<X_{i} \beta\right\}}(1-\theta)\left|Y_{i}-X_{i} \beta\right|\right] .
$$

Intuitively, what this does is estimate $\beta$ at different quantiles by changing the weights $(\theta$ and $1-\theta)$ on the positive and negative residuals. For example, at the median $(\theta=.5)$, positive and negative residuals are given equal weight so that the sum of absolute deviations is minimized. For an excellent nontechnical introduction to quantile regression, see Koenker and Hallock (2001).

Standard errors were calculated using a Huber-White sandwich esti- 
Gender and Math Achievement

mator, adapted for quantile regression. The cluster robust estimator for quantile regression thus takes the form:

$$
\hat{V}_{L A D}=\left(X^{\prime} \hat{F} X\right)^{-1}\left(\sum_{c} X_{c}^{\prime} \hat{\psi}_{c} \hat{\psi}_{c}^{\prime} X_{c}\right)\left(X^{\prime} \hat{F} X\right)^{-1},
$$

where $X_{c}$ is the matrix of independent variables for cluster $c, \hat{F}$ is a kernel estimate of the local density of the residual, and $\hat{\psi}$ is defined as $1-\theta$ if the residual is less than zero and $\theta$ if the residual is greater than or equal to zero. $\hat{F}$ is obtained using Stata's default bandwidth of $.9 \mathrm{~m} / \mathrm{n}^{\frac{1}{5}}$, where $m=\min \left(\sqrt{\text { variance }_{x}}, \frac{\text { interquartilerange }}{1.349}\right)$. This default bandwidth is acceptable, as it goes to zero at a slower rate than $\frac{1}{1 n}$ as $n$ goes to infinity; using $.9 \mathrm{~m} / n^{\frac{1}{3}}$ or $.9 \mathrm{~m} / n^{\frac{1}{3}}$ as the bandwidth did not substantially impact the standard errors.

\section{REFERENCES}

Baron-Cohen, Simon. 2003. The Essential Difference. New York: Basic Books.

Benbow, Camilla P. 1988. "Sex Differences in Mathematical Reasoning Ability in Intellectually Talented Preadolescents: Their Nature, Effects, and Possible Causes." Behavioral and Brain Sciences 11:169-83.

Blum, Deborah. 1997. Sex on the Brain: The Biological Differences between Men and Women. New York: Viking.

Bock, R. Darrell, and Donald Kolakowski. 1973. "Further Evidence of Sex-Linked Major-Gene Influence on Human Spatial Visualizing Activity." American Journal of Human Genetics 25:1-14.

Boles, David B. 1980. "X-linkage of Spatial Ability: A Critical Review." Child Development 51:625-35.

Bracey, Gerald W. 2000. "The TIMSS 'Final Year' Study and Report: A Critique." Educational Researcher 29:4-10.

Bryden, M. Philip. 1986. "Dichotic Listening Performance, Cognitive Ability, and Cerebral Organization." Canadian Journal of Psychology 40:445-56.

Casey, M. Beth, Ronald L. Nuttall, and Elizabeth Pezaris. 1997. "Mediators of Gender Differences in Mathematics College Entrance Test Scores: A Comparison of Spatial Skills with Internalized Beliefs and Anxieties." Developmental Psychology 33:669-80.

Correll, Shelley J. 2004. "Constriaints into Preferences: Gender, Status, and Emerging Career Aspirations." American Sociological Review 69:93-113.

Dar-Nimrod, Ilan, and Steven J. Heine. 2006. "Exposure to Scientific Theories Affects Women's Math Performance." Science 314:435.

Darwin, Charles. 1897. The Descent of Man and Selection in Relation to Sex, $2 \mathrm{~d}$ ed. New York: D. Appleton.

Davies, Paul G., Steven J. Spencer, Dianne M. Quinn, and Rebecca Gerhardstein. 2002. "Consuming Images: How Television Commercials That Elicit Stereotype Threat Can Restrain Women Academically and Professionally." Personality and Social Psychology Bulletin 28:1615-28.

DeFries, J. C., S. G. Vandenberg, and G. E. McClearn. 1976. "Genetics of Specific Cognitive Abilities." Annual Review of Genetics 10:179-207.

Dyson, Freeman. 2007. "Our Biotech Future." New York Review of Books 54:4-8.

Engelhard, George. 1990. "Math Anxiety, Mother's Education, and Mathematics Performance of Adolescent Boys and Girls: Evidence from the United States and Thailand." Journal of Psychology 124:289-98. 


\section{American Journal of Sociology}

Esping-Andersen, Gøsta. 1990. The Three Worlds of Welfare Capitalism. Princeton, N.J.: Princeton University Press.

Favreau, Olga E., and James C. Everett. 1996. "A Tale of Two Tails." American Psychologist 51:268-69.

Feingold, Alan. 1994. "Gender Differences in Variability in Intellectual Abilities: A Cross-cultural Perspective.” Sex Roles 30:81-92.

Frank, Kenneth A., Chandra Muller, Kathryn Schiller, Robert Crosnoe, Catherine Riegle-Crumb, and Anna Strassmann Mueller. 2008. "The Social Dynamics of Mathematics Coursetaking in High School." American Journal of Sociology 113 (6): 1645-96.

Fu, Vincent Kang. 1998. "Estimating Generalized Ordered Logit Models.” Stata Technical Bulletin 8:160-64.

Fuwa, Makiko. 2004. "Macro-level Gender Ineqaulity and the Division of Household Labor in 22 Countries." American Sociological Review 69:751-67.

Gazzaniga, Michael S., Richard B. Ivry, and George R. Magnum. 1998. Cognitive Neuroscience: The Biology of the Mind. New York: Norton.

Geary, David C. 1996. "Sexual Selection and Sex Differences in Mathematical Abilities." Behavioral and Brain Sciences 19:229-84.

. 1998. Male, Female: The Evolution of Human Sex Differences. Washington, D.C.: American Psychological Association.

Geschwind, Norman, and Albert M. Galaburda. 1987. Cerebral Lateralization: Biological Mechanisms, Associations, and Pathology. Cambridge, Mass.: MIT Press.

Gill, Harwant S., and Michael W. O'Boyle. 1997. "Sex Differences in Matching Circles and Arcs: A Preliminary EEG Investigation." Laterality 2:33-48.

Guo, Guang, and Elizabeth Stearns. 2002. "The Social Influences on the Realization of Genetic Potential for Intellectual Development." Social Forces 80:881-910.

Halpern, Diane F. 2000. Sex Differences in Cognitive Abilities. Mahwah, N.J.: Lawrence Erlbaum Associates.

Hampson, Elizabeth. 1990. "Estrogen-Related Variations in Human Spatial and Articulatory Motor Skills." Pyschoneuroendocrinology 15:97-111.

Hampson, Elizabeth, Joanne F. Rovet, and Deborah Altmann. 1998. "Spatial Reasoning in Children with Congenital Adrenal Hyperplasia due to 21-Hydroxylase Deficiency." Developmental Neuropsychology 14:299-320.

Handcock, Mark S., and Martina Morris. 1999. Relative Distribution Methods in the Social Sciences. New York: Springer.

Harnisch, Delwyn L., Marjorie W. Steinkamp, Shiow-Ling Tsai, and Herbert J. Walberg. 1986. "Cross-national Differences in Mathematics Attitude and Achievement among Seventeen-Year-Olds." International Journal of Educational Development 6:233-44.

Hedges, Larry V., and Amy Nowell. 1995. "Sex Differences in Mental Test Scores, Variability, and Numbers of High-Scoring Individuals." Science 269:41-45.

Inzlicht, Michael, and Talia Ben-Zeev. 2000. "A Threatening Environment: Why Females Are Susceptible to Experiencing Problem-Solving Deficits in the Presence of Males." Psychological Science 11:365-71.

Kimura, Doreen. 1999. Sex and Cognition. Cambridge, Mass.: MIT Press.

Kimura, Doreen, and Elizabeth Hampson. 1994. "Cognitive Pattern in Men and Women Is Influenced by Fluctuations in Sex Hormones." Current Dirrections in Psychological Science 3:57-61.

Koenker, Roger, and Gilbert Basset. 1978. "Regression Quantiles." Econometrica 46: $33-50$.

Koenker, Roger, and Kevin F. Hallock. 2001. "Quantile Regression.” Journal of Economic Perspectives 15:143-56.

Levin, Jesse. 2001. "For Whom the Reductions Count: A Quantile Regression Analysis 
Gender and Math Achievement

of Class Size and Peer Effects on Scholastic Achievement." Empirical Economics 26:221-46.

Levy, Jerre. 1974. "Hemisphere Function in the Human Brain." Pp. 121-83 in Psychobiological Implications of Bilateral Asymmetry, edited by Stuart J. Dimond and John G. Beaumont. New York: Wiley.

Lovaglia, Michael J., Jeffrey W. Lucas, Jeffrey A. Houser, Shane R. Thye, and Barry Markovsky. 1998. "Status Processes and Mental Ability Test Scores." American Journal of Sociology 104:195-228.

Ma, Xin. 2001. "Participation in Advanced Mathematics: Do Expectation and Influence of Students, Peers, Teachers, and Parents Matter?" Contemporary Educational Psychology 26:132-46.

Martin, Michael O., and Dana L. Kelly. 1996. Third International Mathematics and Science Study Technical Report. Vol. 1: Design and Development. Chestnut Hill, Mass.: Boston College, Center for the Study of Testing, Evaluation, and Educational Policy.

McClearn, Gerald E., Boo Johansson, Stig Berg, Nancy L. Pedersen, Frank Ahern, Stephen A. Petrill, and Robert Plomin. 1997. "Substantial Genetic Influence on Cognitive Abilities in Twins 80 or More Years Old." Science 276:1560-63.

Moffat, Scott D., and Elizabeth Hampson. 1996. "A Curvilinear Relationship between Testosterone and Spatial Cognition in Humans: Possible Influence of Hand Preference." Pyschoneuroendocrinology 21:323-37.

Mullis, Ina V. S., Michael O. Martin, Edward G. Fierros, Amie L. Goldberg, and Steven E. Stemler. 2000. Gender Differences in Achievement: IEA's Third International Mathematics and Science Study. Chestnut Hill, Mass.: Boston College, International Study Center.

Nowell, Amy, and Larry V. Hedges. 1998. "Trends in Gender Differences in Academic Achievement from 1960 to 1994: An Analysis of Differences in Mean, Variance, and Extreme Scores." Sex Roles 39:21-43.

Petrill, Stephen A. 1997. "Molarity versus Modularity of Cognitive Functioning? A Behavioral Genetic Perspective." Current Directions in Psychological Science 6: 96-99.

Pinker, Stephen. 2002. The Blank Slate. New York: Viking.

Plomin, Robert, and Ian Craig. 2001. "Genetics, Environment and Cognitive Abilities: Review and Work in Progress towards a Genome Scan for Quantitative Trait Locus Associations Using DNA Pooling." British Journal of Psychiatry 178:s41-s48.

Plomin, Robert, David W. Fulker, Robin Corley, and John C. DeFries. 1997. "Nature, Nuture, and Cognitive Development from 1 to 16 Years: A Parent-Offspring Adoption Study." Psychological Science 8:442-47.

Resnick, Susan M., Sheri A. Berenbaum, Irving I. Gottesman, and Thomas J. Bouchard. 1986. "Early Hormonal Influences on Cognitive Functioning in Congenital Adrenal Hyperplasia.” Developmental Psychology 22:191-98.

Riegle-Crumb, Catherine. 2005. "The Cross-national Context of the Gender Gap in Math and Science." Pp. 227-43 in The Social Organization of Schooling, edited by Larry V. Hedges and Barbara Schneider. New York: Russell Sage Foundation.

Sato, Tatsuya, Hiroshi Namiki, Juko Ando, and Giyoo Hatano. 2004. "Japanese Conception of and Research on Human Intelligence." Pp. 302-24 in International Handbook of Intelligence. New York: Cambridge University Press.

Spencer, Steven J., Claude M. Steele, and Dianne M. Quinn. 1999. "Stereotype Threat and Women's Math Performance." Journal of Experimental Social Psychology 35: 4-28.

Steinkamp, Marjorie W., Delwyn L. Harnisch, Herbert J. Walberg, and Shiow-Ling Tsai. 1985. "Cross-national Gender Differences in Mathematics Attitude and Achievement among 13-Year-Olds." Journal of Mathematical Behavior 4:259-77.

Stumpf, Heinrich, and Julian C. Stanley. 1996. "Gender-Related Differences on the 


\section{American Journal of Sociology}

College Board's Advanced Placement and Achievement Tests, 1982-1992." Journal of Educational Psychology 88:353-64.

Summers, Lawrence H. 2005. "Remarks at NBER Conference on Diversifying the Science and Engineering Workforce." http://www.president.harvard.edu/speeches/ 2005/nber.html. Retrieved June 15, 2005.

Thomas, Hoben, and Robert Kail. 1991. "Sex Differences in Speed of Mental Rotation and the X-Linked Genetic Hypothesis." Intelligence 15:17-32.

U.S. Congress. 2000. A Review of the Morella Commission Report. Washington, D.C.: Government Printing Office.

Walton, Gregory M., and Geoffrey L. Cohen. 2003. "Stereotype Lift." Journal of Experimental Social Psychology 39:456-67.

Wright, Margie, Eco De Geus, Juko Ando, Michelle Luciano, Danielle Posthuma, Yutaka Ono, Narelle Hansell, Caroline Van Baal, Kai Hiraishi, Toshikazu Hasegawa, Glen Smith, Gina Geffen, Laurie Geffen, Shigenobu Kanba, Akira Miyake, Nick Martin, and Dorret Boomsma. 2001. "Genetics of Cognition: Outline of a Collaborative Twin Study." Twin Research 4:48-56.

Xie, Yu, and Kimberlee A Shauman. 2003. Women in Science. Cambridge, Mass.: Harvard University Press. 